\title{
MICROSTRUCTURAL AND COMPOSITIONAL CHARACTERIZATION OF NABATAEAN POTTERIES FROM KHIRBET ED-DHARIH IN THE HOLY LAND OF JORDAN
}

\author{
MIKROSTRUKTURNA IN MIKROKEMIJSKA KARAKTERIZACIJA \\ NABATEJSKEGA LONČARSTVA V KHIRBET ED-DHARIH \\ V SVETI DEŽELI JORDANIJE
}

\author{
Wassef Al Sekhaneh" ${ }^{*}$, Mahmoud Arinat ${ }^{2}$, Zeidoun Al Muheisen' \\ ${ }^{1}$ Department of Archaeology, Faculty of Archaeology and Anthropology, Yarmouk University-Irbid-Jordan, Shafiq Irshidat Street, \\ 21162 Irbid, Jordan \\ ${ }^{2}$ Department of Cultural Resources Management and Conservation, School of Archaeology and Tourism, University of Jordan, \\ Amman, 11942, Jordan
}

Prejem rokopisa - received: 2020-05-26; sprejem za objavo - accepted for publication: 2020-08-05

doi:10.17222/mit.2020.090

\begin{abstract}
This paper presents spectroscopic results from ancient Nabateans egg-shell pottery remains excavated from the ancient site of Khirbet al - Dharih; it belongs to the first century AD. FTIR spectroscopy, SEM-EDX-, OM-, and XRD methods were used in the analyses of both colored and uncolored parts of the sherds. All were applied in order to estimate the upper-temperature limit of the firing temperature of the pottery sherds. The samples were heated to a temperature of about $1000^{\circ} \mathrm{C}$ and $1100{ }^{\circ} \mathrm{C}$. A comparison of the FTIR spectra of the original and the corresponding refired ceramic fragments allows us to estimate the upper-temperature limit of firing, to determine the mineral composition and the firing conditions. The spectroscopic results showed that the ceramics were fired in oxidizing conditions up to a temperature of less than $1000{ }^{\circ} \mathrm{C}$ as a calcareous-poor type.

Keywords: Khirbet al - Dharih, ancient pottery, Nabataean, firing temperature, calcareous, egg-shell, FTIR, SEM-EDX, XRD
\end{abstract}

V članku avtorji predstavljajo rezultate spektroskopije ostankov starodavnih lončarskih izdelkov Nabatejskega ljudstva, izdelanih s tehniko jajčne lupine (angl.: Nabateans egg-shell pottery), izkopanih na ostankih starodavnega mesta Khirbet al Dharih, ki izhajajo iz prvega stoletja našega štetja. Za analize obarvanih in neobarvanih razbitih delov lončevine so uporabili FTIR-spektroskopijo, SEM-EDX-, OM-, in XRD-metode. Analize so izvedli zato, da bi ocenili najvišjo temperaturo žganja lončevine. Vzorce lončevine so ogreli na temperaturo okoli $1000{ }^{\circ} \mathrm{C}$ in $1100{ }^{\circ} \mathrm{C}$. Primerjava FTIR-spektrov originalnih in med preizkusi žganih ostankov lončevine, jim je omogočila oceniti njihovo maksimalno temperaturo žganja, določiti mineralno sestavo in pogoje žganja. Rezultati spektroskopije so pokazali, da je bila keramika žgana v oksidativni atmosferi pri temperaturah nižjih od $1000{ }^{\circ} \mathrm{C}$ in je imela majhno vsebnost kalcijevega oksida.

Ključne besede: Khirbet al - Dharih, starodavno lončarstvo, Nabatejci, temperatura žganja, apnenčast, jajčna lupina, FTIR, SEM-EDX, XRD

\section{INTRODUCTION}

Ancient Khirbet al - Dharih is one of the most important archaeological sites in Jordan. It is not far from the ancient city Petra, the capital of Nabataeans, the famous city with red sandstone, the incredible place, Khirbet al Dharih site founded on the King's Highway and not far from the north coast of the Red Sea, in the southern part of Jordan, at the crossroads of seaways and the Silk Road, which connect Egypt with the north of the Arabian Peninsula and with the rest of the world. From a cultural-historical point of view, its importance lies not only in the fact that it is located on the essential transitional route where cultural contacts between the aforementioned regions are established, but Khirbet al - Dharih not far from Petra, the important center of painted egg-shell pottery with a wall thickness of about two mm. The first inhabitants of Khirbet al - Dharih are not yet

*Corresponding author's e-mail:

sekhaneh@yu.edu.jo (Wassef Al Sekhaneh) known, but the remains show that the first inhabitants can be dated to about 4000 years ago, in different periods (Mumlouki, Ummayyed, Byzantine, Nabataean, Roman, Iron, and Bronze age). ${ }^{36,37}$ Khirbet al - Dharih was inhabited by the Edomite before the arrival of the Nabateans, the latter carved magnificent buildings, temples, and tombs from massive sandstone rock and life in Petra continues to this day. The flower and leaf designs are often found with geometric motifs such as dots and lattices which connect the floral motifs. 5,34,36 There are two types of pottery depending on the firing process: oxidation (red ceramics) or reduction (black ceramics), which changes the reduced black magnetite iron oxide to the red oxide form. ${ }^{16,19}$ An interdisciplinary approach is essential in the study of heritage objects. Degradation of ancient material in the general state of conservation and restoration of the work is made worse by the interaction of atmospheric pollution, hazardous gases, light and other environmental causes, and the duration of the environmental fluctuation and interaction with the objects. ${ }^{7}$ 
Currently, all the important museums around the world have significantly increased their dependency on teams of physicists and chemists to help in the field of conservation. The conservation plan applied to the works of cultural heritage has to consider cultural and scientific aspects. The intervention of analytical chemists in the conservation field is crucial..$^{7,22,30}$ The analytical information obtained is given to the conservator to provide a scientific analysis of the conservation circumstances and necessary information on the chemical properties of the ancient materials that might be exposed to restoration work. Among other analytical problems, specific limits on the sampling ${ }^{27}$ and preliminary treatments ${ }^{7,21}$ have to be resolved, which are due to the characteristics of the artifacts in the study as works of full cultural value whose loss would be severe because they are scarce, valuable and no-renewable. The main analytical issue in conservation is the identification of organic and inorganic components in works of art. ${ }^{7,20,35}$ Other analytical studies aim to clarify the influence of the environmental factors (e.g., light, hazardous gases, temperature, and humidity), ${ }^{6,11}$ biological agents, ${ }^{38}$ and atmospheric air pollution on the deterioration process of these types of materials. ${ }^{17}$ This approach should be carried out to design a preventive conservation treatment. In these treatment programs, the identification and quantification of the above alteration agents are essential. The analytical chemist and physicist are also required when the restoration of heritage objects is fixed on, to support the process applied in each step, cleaning agents, protective agents, solvents, and the most effective characterization methods. ${ }^{7,12}$

The aim of this study is to investigate the chemical composition of the pottery matrix, the production techniques of the archaeological ceramic, the firing conditions for egg-shells sherds were collected at the ancient site of Petra. The nature of the raw materials and the technology used to make the potteries, which is essential because the extracted knowledge from the ancient materials gives us a better understanding of the civilization that created the potteries and provides us with information for conservation and restoration techniques. On the other hand, the identification of the coloring used in antiquity is an important factor for the restoration, conservation, age determination, and authenticity of the artifacts. The microstructure of pottery compositions was investigated and characterized by X-ray diffraction (XRD), field-emission scanning electron microscopy (FE-SEM) combined with energy-dispersive X-ray spectrometry (EDX) have been used to demonstrate these as potential tools for pottery study.

\subsection{Excavation site}

Khirbet al - Dharih is situated on the King's Highway, in the Wadi al-Laaban, a southern tributary of Wadi al-Hesa, $12 \mathrm{~km}$ to the north of Tafileh and $7 \mathrm{~km}$ to the south of the high-altitude sanctuary at Khirbet et-Tan- nour, where Khirbet al - Dharih is closely associated. It was first recognized in 1818 by Irby and Mangles, and visited later by Brunnow and Von Domasze. Also Glueck refers in brief to the temple, also visited by McDonald during the Wadi el-Hasa survey and refers to the temple as the main architectural remains at the site (Figure 2). About $100 \mathrm{~km}$ north of Petra, Khirbet al - Dharih is a rural site on the high road that connects Damascus and Bosra in Syria with Petra and the port of Aqaba/Ayla on the Red Sea. The location of the site is shown on the map of Jordan (Figure 1). The works in Khirbet al - Dharih are of particular interest if one remembers that this site of permanent habitat is located $7 \mathrm{~km}$ from the famous high sanctuary of Tannur, also Nabataean, an isolated sanctuary excavated in the 1930s and the course of re-publication by Judith McKenzie, the sanctuary that we reinterpret now as a small shrine for occasional pilgrimages, dependent on Khirbet al - Dharih: a place of procession for the gods domiciled in Khirbet al - Dharih: a reinterpretation that met with no opposition. The chronology encountered in Khirbet al - Dharih is simple, marked by numerous periods and numerous cuts or dropouts. We have traces of occupations in the Ancient bronze age ( $3^{\text {rd }}$ millennium $\left.\mathrm{BC}\right)$ and in the Iron age II, the Edomite period ( $6^{\text {th }}$ to $5^{\text {th }}$ centuries $\mathrm{BC}$ ), then a gap in the Hellenistic period. The main occupation lasted from the beginning of the $1^{\text {st }}$ century AD until the 360 AD. The excavated pottery sherds in this study were from the Late Nabataean Early Roman period. 2,5,14,18,26,33,36,37

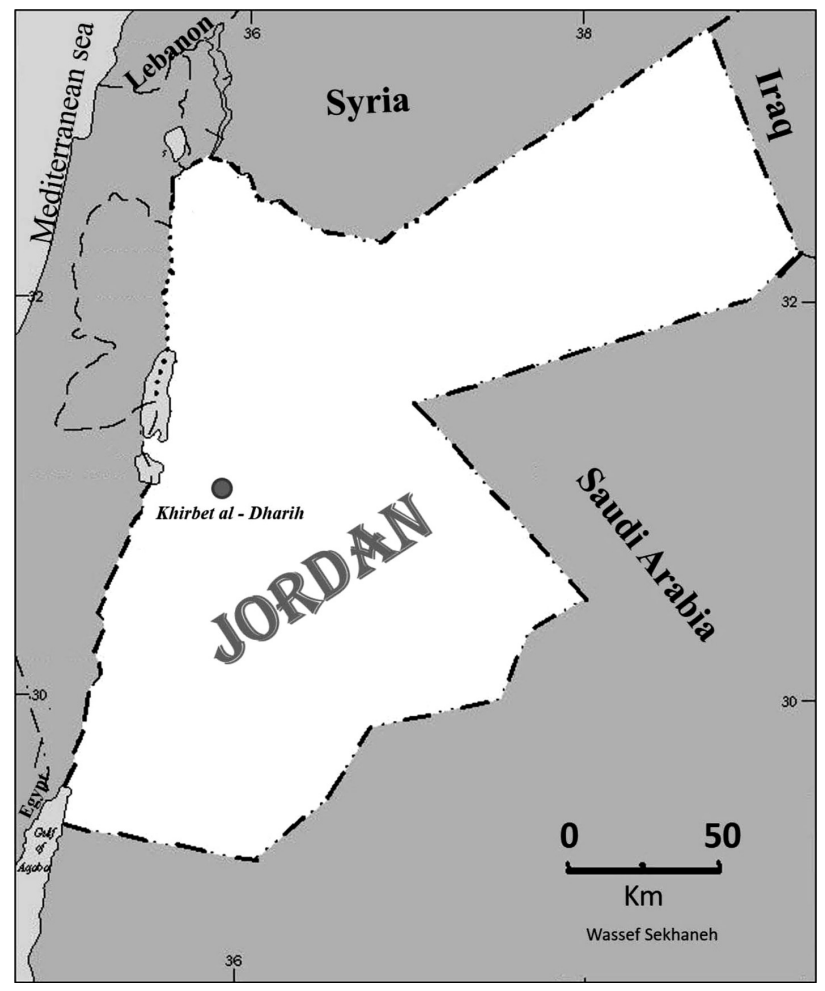

Figure 1: Jordan map showing Khirbet Khirbet al - Dharih archaeological site 

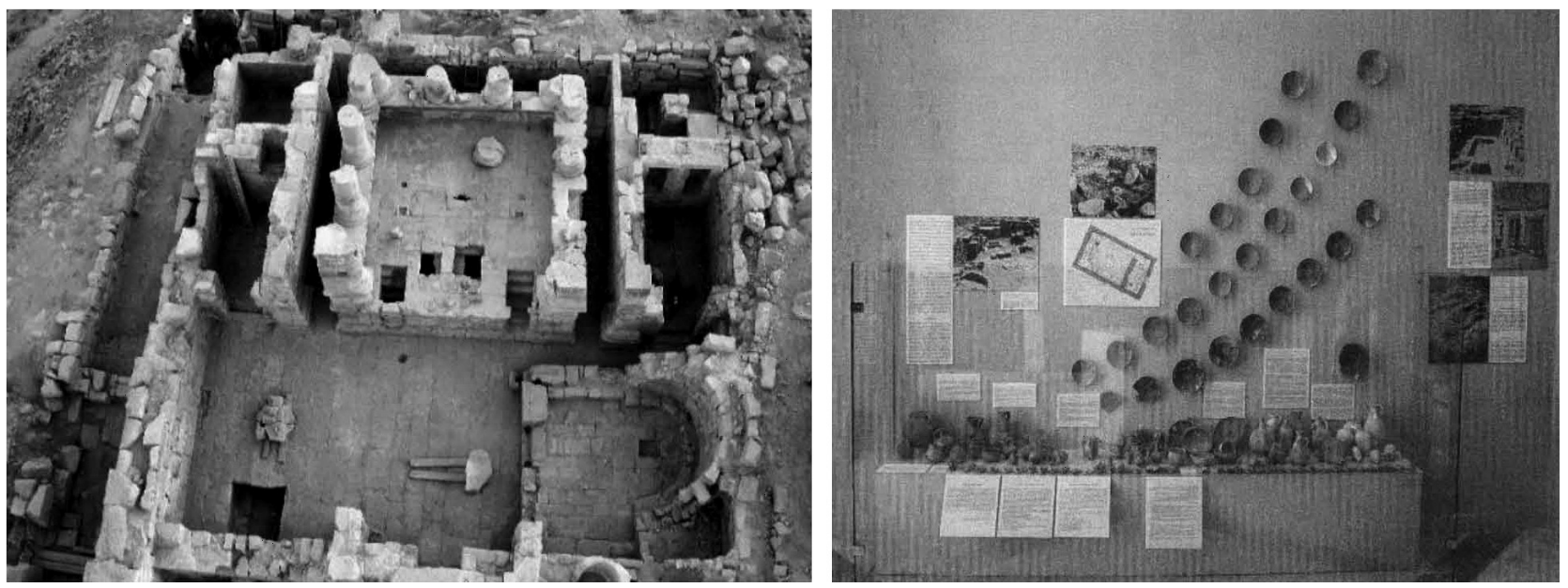

Figure 2: a) Top view of the temple of Khirbet al - Dharih, b) The Nabatean pottery pavilion at City Hall - Greater Amman Municipality (Zeidoun Al Muheisen)

\section{MATERIALS AND METHODS}

The microstructure of the pottery compositions was investigated and characterized by X-ray diffraction (XRD), field-emission scanning electron microscopy (FE-SEM) combined with energy-dispersive X-ray spectrometry (EDX) in IPHT, Jena/ Germany. The mineralogical composition of the pottery was determined using a Shimadzu LabX, XRD-6000 X-ray diffractometer at Yarmouk University, Jordan. A small amount of the pottery powder from a colored fragment was taken, then mixed and dispersed in ethanol and spread on a microscopic glass slide. After the evaporation of ethanol, the slide was brought into the XRD instrument for analysis. A copper $\mathrm{KL}_{2,3}\left(\alpha_{1,2}\right)$ radiation $(\lambda=0.15418 \mathrm{~nm})$ source was used for all the sample patterns investigated, and the spectrum was acquired at $40 \mathrm{kV}, 30 \mathrm{~mA}$ and a step size of $0.05^{\circ}$ in $2 \theta$ from 10 to 60 , the analysis of the minerals was performed with a PANalytical's diffractometer and X'Pert High Score software.

SEM combined with EDX was used to examine the elemental compositions of the patinas products and core metal. This technique was used in order to obtain further information about the nature of the mineral compositions that would not have appeared in the XRD spectrum. The

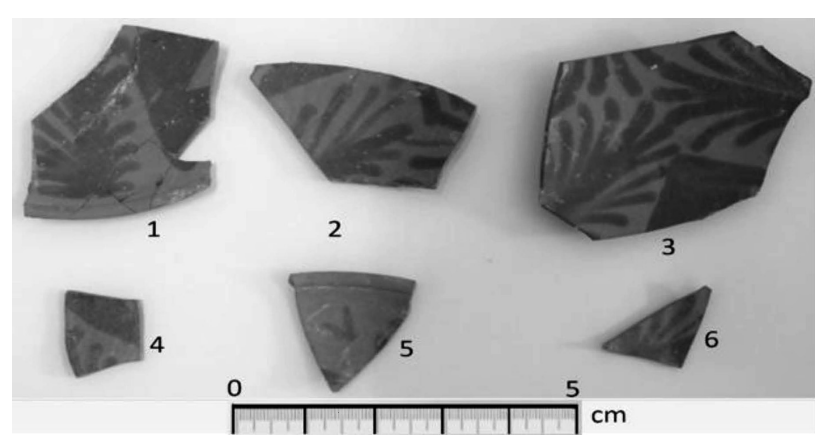

Figure 3: Photographs of the examined pottery sherds. Fragment of black-figured egg-shell pottery (first century A.D.); specimen fragment of a plate with decorated red pattern in black.
SEM-EDX investigation was carried out using a high-resolution field-emission electron microscope JSM-6300F combined with a microprobe analyzer JXA-8800 L (JEOL, Japan). The SEM. micrographs were taken using the ordinary secondary-electron (SE) mode that is more often used to show the morphology and topography of the sample. The energy-dispersive X-ray spectrometry EDX was used for a qualitative elemental identification. To this end, a silicon drift detector (SDD) X-flash 5010 (BRUKER-Nano company, Germany) was used.

The examined egg-shell pottery sherds are shown in Figure 3. The FTIR spectra of the powder samples pressed in $\mathrm{KBr}$ discs were collected with a Tensor 27 FTIR spectrometer. The spectra were obtained as the average of five measurements. Spectral manipulations like baseline fitting, smoothing, and calculations of the second derivative were performed with the software package Omnic (Thermo Nicolet Corporation, Madison, WI, USA).

\section{RESULTS AND DISCUSSION}

Figure 4 shows the XRD spectra from the surface of two fragments, uncolored part (b) and black colored, decorated part of the fragment (a), the XRD spectrum of black colored area shown in Figure 4 (uncolored area).

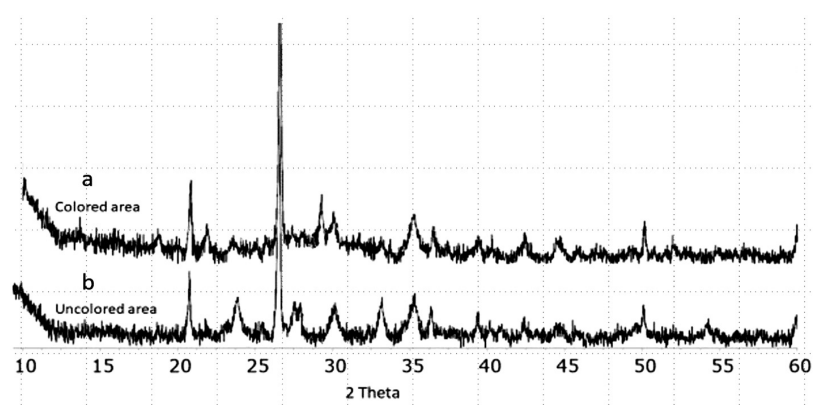

Figure 4: XRD Spectra of: a) black-colored area, and b) spectra of uncolored area 


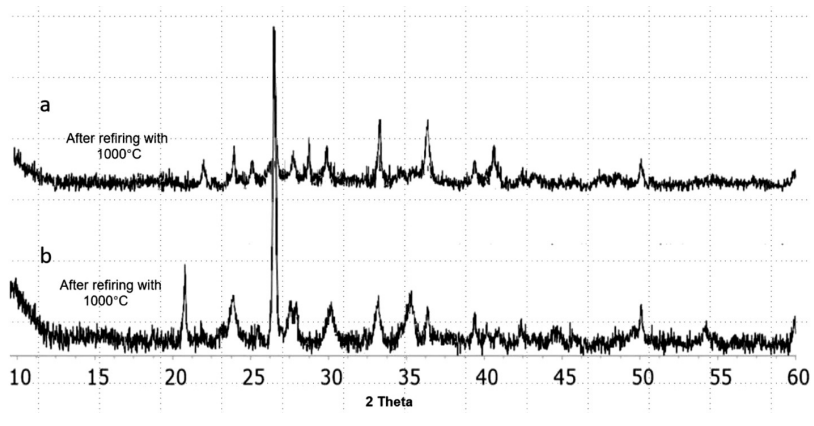

Figure 5: XRD pattern of the sherd of a plate after refiring with $1000{ }^{\circ} \mathrm{C}$ and $1100{ }^{\circ} \mathrm{C}$

The XRD spectra of the investigated colored samples showed features of quartz at $(2 \theta=20.70,26.64,36.51$, 42.51, and 45.80) and feldspar Ca-Na feldspar/ (Ca, Na) $\left.\mathrm{AlSi}_{3} \mathrm{O}_{8}\right)$ (sanidine $=(2 \theta=24.12,25.81$, and 27.50); $\mathrm{K}-\mathrm{Na}$ feldspar/ $\left.(\mathrm{K}, \mathrm{Na}) \mathrm{AlSi}_{3} \mathrm{O}_{8}\right)(2 \theta=23.12$, and 27.11); Åkermanite $\mathrm{CaMgSi}_{2} \mathrm{O}_{6}=31.21$; calcite = 29.21, 39.76; hematite/ $\mathrm{Fe}_{2} \mathrm{O}_{3}(2 \theta=33.82$, and $35.75,49.71)$ peaks. The XRD spectrum of the investigated samples showed common features of quartz after refiring to a) $1000{ }^{\circ} \mathrm{C}$ and b) $1110{ }^{\circ} \mathrm{C}$. Figure 5, shows the location of the mineral band in the sample, Quartz $(2 \theta=20.70,26.64$, $36.51,42.51$, and 45.80) ; and feldspar Ca-Na feldspar/ $\left.(\mathrm{Ca}, \mathrm{Na}) \mathrm{AlSi}_{3} \mathrm{O}_{8}\right)$ (sanidine $=(2 \theta=24.12,25.81$, and 27.50); K-Na feldspar/ $\left.(\mathrm{K}, \mathrm{Na}) \mathrm{AlSi}_{3} \mathrm{O}_{8}\right)(2 \theta=23.12$, and 27.11).

Åkermanite $\mathrm{Ca}_{2} \mathrm{MgSi}_{2} \mathrm{O}_{7}=30.11,40.05$ and 50.11; hematite/ $\mathrm{Fe}_{2} \mathrm{O}_{3}(2 \theta=33.82$, and $35.75,49.71)$ peaks and calcite was disappeared. Figure $\mathbf{5 b}$ at $1100 \mathrm{C}$ shows the location of mineral XRD band in the sample, it is a feldspar Ca-Na feldspar/ $\left.(\mathrm{Ca}, \mathrm{Na}) \mathrm{AlSi}_{3} \mathrm{O}_{8}\right)($ sanidine $=(2 \theta=$ $24.12,27.51,29.80,30.21)$; mullite $3 \mathrm{Al}_{2} \mathrm{O}_{3} 2 \mathrm{SiO}_{2}=(2 \theta=$ 26.50 and 30.11, and 40.05); hematite/ $\mathrm{Fe}_{2} \mathrm{O}_{3}(2 \theta=$ 33.82 , and 35.23).

The X-ray diffraction patterns of the samples obtained at different annealing temperatures are shown in Figure 5. In the case of the characterized sample, it shows an amorphous nature, but with heat treatment at $1000{ }^{\circ} \mathrm{C}$, peaks of $\mathrm{SiO}_{2}$ could be observed. Increasing the annealing temperature further to $1100{ }^{\circ} \mathrm{C}$ results in the quartz $\mathrm{SiO}_{2}$ at $(2 \theta=20.70,26.64,36.51,42.51$, and 45.80) peaks all disappearing as amorphous silica. Whereas, the peaks obtained at $1100{ }^{\circ} \mathrm{C}$ show the sharp peaks of feldspar; the rise of a new mineral called mullite formed from $\gamma-\mathrm{Al}_{2} \mathrm{O}_{3}$ and amorphous silica and haematite with the complete disappearance of alumina and quartz peaks.

$\mathrm{Na}, \mathrm{Mn}$, and Ti were found as smaller fractions in the samples. EDX analyses support the vibrational spectroscopy results. The presence of aluminosilicates, quartz, iron oxides (hematite and magnetite), feldspars, gypsum, $\mathrm{MnO}_{2}$ and $\mathrm{TiO}_{2}$ is discussed below. The normal XRF is a limited one and cannot unambiguously determine the $\mathrm{Na}$ peak in the samples. Therefore, the $\mathrm{Na}$ concentration of the investigated pottery samples was analyzed by the SEM-EDX method. As a result, the $\mathrm{Na}_{2} \mathrm{O}$ concentration of the investigated samples was found in the range $0.45-0.78 \%$. The presence of Na results supports the vibrational spectroscopic investigation of the presence of albite (Na-feldspar) in the FTIR mineralogical identification.

The elemental concentrations of the potteries examined under SEM-EDX are given in Table 1. the chemical composition for eight Nabataean fine pottery samples (1-8) as determined by the SEM-EDX average composition expressed in the oxide form (weight $\%$ normalized to 100 weight $\%$ ) for the six uncolored samples and two colored samples. The results show that all the pottery samples are constituted mainly of Si and Al. These elements are associated with clay structures, quartz, and feldspars. The $\mathrm{SiO}_{2}$ varies from $57 w / \%$ to $53 \mathrm{w} / \%$, $\mathrm{Al}_{2} \mathrm{O}_{3}$ is between $19 w / \%$ and $22 w / \%$, and $\mathrm{FeO}$ is between $7 w / \%$ and $8 w / \%$. The iron oxide in the colored samples is relatively high (16-18 w/\%), in approximately the same percentage in samples 1-4 and 7-8, the different percentage from the colored sample 5C and 6C (refired sample). It is clear that all the samples are of a calcareous-poor type, and all the samples have a high percentage of iron oxide content, more particularly refired and colored samples 5C, and refired uncolored sample 6C.

The EDX for the black colored and uncolored pottery sherds show the same source of raw materials, considered as calcareous-poor type; the ancient potters have been used throughout their pottery production process, either by using calcareous clays or by adding calcite-temper to the clay paste or both for the development of the viscosity of the batch. ${ }^{25}$ The egg-shell pottery in Khirbet al - Dharih was manufactured with calcareous-poor clay, and the firing temperature was about

Table 1: Chemical composition for eight Nabataean fine pottery samples (1-8) as determined by SEM-EDX

\begin{tabular}{|c|c|c|c|c|c|c|c|c|c|c|}
\hline Sherds no. & $\mathrm{SiO}_{2}$ & $\mathrm{Al}_{2} \mathrm{O}_{3}$ & $\mathrm{FeO}$ & $\mathrm{CaO}$ & $\mathrm{MgO}$ & $\mathrm{K}_{2} \mathrm{O}$ & $\mathrm{Na}_{2} \mathrm{O}$ & $\mathrm{TiO}_{2}$ & $\mathrm{MnO}$ & $\mathrm{Sum}$ \\
\hline 1 & 57.82 & 20.63 & 7.32 & 7.33 & 2.87 & 2.12 & 0.45 & 1.04 & 0.42 & 100 \\
\hline 2 & 55.91 & 21.21 & 6.45 & 8.91 & 3.45 & 2.27 & 0.71 & 0.78 & 0.31 & 100 \\
\hline 3 & 56.98 & 20.01 & 7.23 & 8.07 & 3.32 & 2.78 & 0.64 & 0.79 & 0.18 & 100 \\
\hline 4 & 53.17 & 21.98 & 8.56 & 8.66 & 3.64 & 2.29 & 0.49 & 1.02 & 0.19 & 100 \\
\hline 5 & 55.13 & 22.49 & 8.23 & 7.12 & 2.58 & 2.66 & 0.65 & 0.97 & 0.17 & 100 \\
\hline 6 & 56.69 & 20.88 & 7.31 & 8.35 & 2.91 & 1.94 & 0.72 & 1.01 & 0.19 & 100 \\
\hline $5 \mathrm{C}$ & 46.56 & 20.33 & 6.991 & 7.98 & 3.28 & 2.93 & 0.78 & 1.01 & 0.14 & 100 \\
\hline $6 \mathrm{C}$ & 44.91 & 19.94 & 8.191 & 8.13 & 3.78 & 3.18 & 0.54 & 1.12 & 0.21 & 100 \\
\hline
\end{tabular}



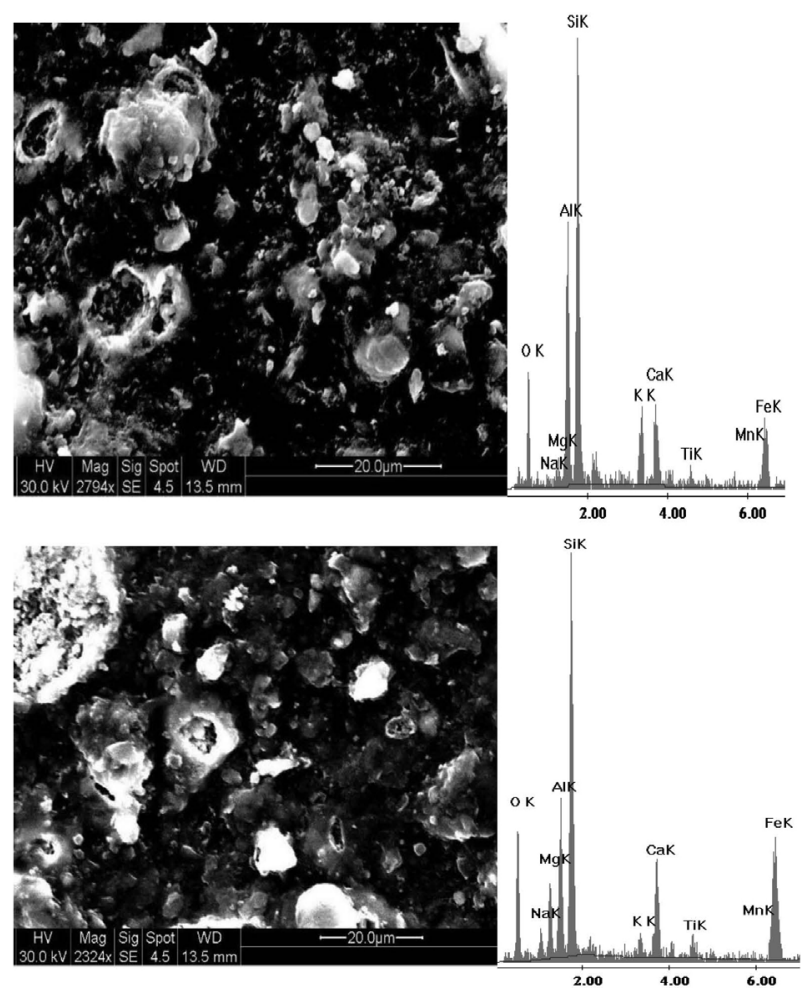

Figure 6: a) SEM-EDX spectrum of the uncolored part of the egg-shell pottery plate (sample 5), b) SEM-EDX spectrum of the black-colored part of the egg-shell pottery plate (sample 5), and the EDX spectrum of the black-colored part of sample 4 is shown right of the picture, a large amount of $\mathrm{Fe}, \mathrm{Si}, \mathrm{Al}$ was observed in the sample.

$900{ }^{\circ} \mathrm{C}$ in an oxidizing atmosphere with no vitrification stage, as shown in the SEM images of sample 4 in Figure 7. The existence of hematite and red pottery indicates that the firing of the ceramic was performed in an oxidizing atmosphere..$^{3,28,29}$

SEM micrograph are shown in Figure 7, the figures related to samples 5, Figure 7 show that they are not in an extensive vitrification stage. From the chemical analysis, it has also been characterized that the samples were
Calcareous-poor type and were fired in an oxidizing atmosphere.

As indicated by ${ }^{6}$, whether calcareous, poor-calcareous or non-calcareous the low refractory clays fired in oxidizing conditions with an extensive vitrification stage, the Nabatean pottery as shown in the study were fired in the range $850-950{ }^{\circ} \mathrm{C}$. These samples were refired at $1000{ }^{\circ} \mathrm{C}$ and $1100{ }^{\circ} \mathrm{C}$ in an oxidizing atmosphere, and an extensive vitrification stage is detected by the SEM images (Figures $\mathbf{7 b}$ and $\mathbf{7 c}$ ) the color of the verified sample converted to light black by $1100{ }^{\circ} \mathrm{C}$. The total vitrification stage was at a temperature of $1100{ }^{\circ} \mathrm{C}$. Figure 7 also shows that the vitrification was first detected by SEM at $1000{ }^{\circ} \mathrm{C}$ for sample 5c (Figure 7b), and verified by 1100 ${ }^{\circ} \mathrm{C}$ (Figure 7c). The presence or absence of characteristic phases in pottery, which were made of non-calcareous or calcareous clays, reveals the firing temperature. For example, if the raw material contained mica and kaolinite, the presence of kaolinite in the ceramic sherd without ambiguity indicates a firing temperature below $600{ }^{\circ} \mathrm{C}$, while the absence of mica indicates a firing temperature above $1000{ }^{\circ} \mathrm{C}$. The kaolinite and clay are essential in the component of pottery raw materials because their nanoparticles permitted controlling the viscosity of the batch. The temperature prerequisite to reach the densification of pottery, an assembly of grains, depends on the grain size. Nature offers a variety of nanosized materials that possess exceptional properties of viscosity after their mixing with water ${ }^{10}$ through their interaction with the water molecules and of the sintering through their reactivity. ${ }^{8-10}$ Gehlenite and diopside are formed from calcareous clays under oxidizing conditions at $750{ }^{\circ} \mathrm{C}$ and $850{ }^{\circ} \mathrm{C}$, respectively, and under reducing conditions at $850{ }^{\circ} \mathrm{C}$ and $950{ }^{\circ} \mathrm{C}$, respectively. ${ }^{1,4,13}$ The existence of mullite and amorphous silica in the pottery indicates that the firing temperatures wereabove $1000{ }^{\circ} \mathrm{C}$. The Nabataean pottery has no mullite as found, which means the temperature that was used was either not reached at all or not sustained over a more extended period in the Nabataean kilns.
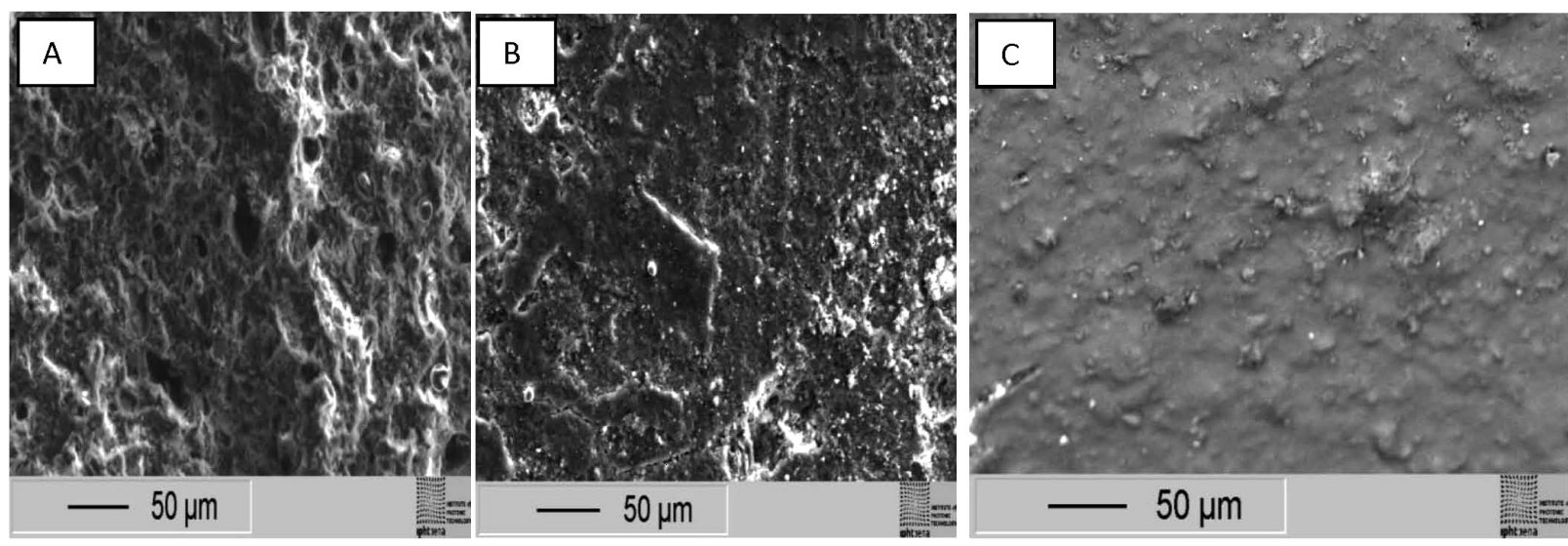

Figure 7: Sample $5 \mathrm{c}$ has an unvitrified pottery surface (a), sample $5 \mathrm{c}$ was fired in an oxidizing atmosphere, but the vitrification of the sample is not clear and the micrograph shows a large amount of pores in sample (a), the first vitrification of the sample in the initial stage (b), the fully vitrified surface (c). 


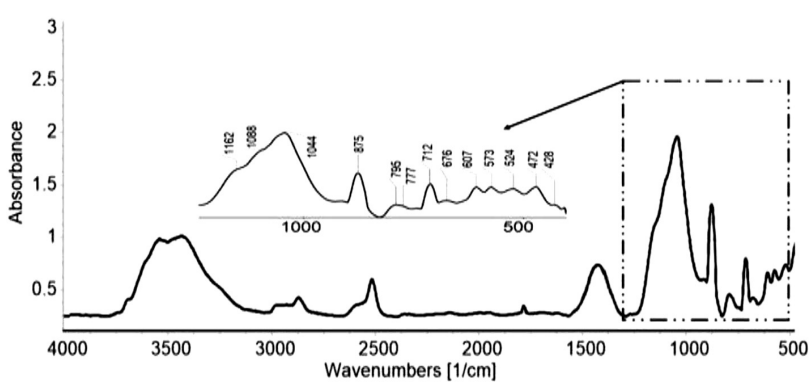

Figure 8: FTIR spectra of the sherd part of the calcareous-poor type sample 5 , the fragment of a plate from $\left(1^{\text {st }}\right.$ century AD).

The $1300-400 \mathrm{~cm}^{-1}$ range of the FTIR spectrum of the sample 5 profile is shown in Fig. 8. The FTIR absorption spectrum allowed us to investigate the mineral phases existing in the ceramic sample. Therefore, the main component of the ceramic body was quartz with bands found at $(1162,1088,795,777,676$, and 524) $\mathrm{cm}^{-1}$. The peak around $1044 \mathrm{~cm}^{-1}$ is the result of the red clay origin of kaolinite. ${ }^{23,24}$ For the existence of calcareous or calcite $\mathrm{CaCO}_{3}$, calcite is present as an impurity of the local clays. The observation of calcite $\left(\mathrm{CaCO}_{3}\right)$ bands at $1442 \mathrm{~cm}^{-1}$ and $875 \mathrm{~cm}^{-1}$ allows us to conclude the firing temperature. In the firing of calcite material composed of a mixture of clay microcrystalline and minerals calcite, the calcite starts to decompose above $600{ }^{\circ} \mathrm{C}$, carbon dioxide gas $\left(\mathrm{CO}_{2}\right)$ is released, and free-lime or quick lime $(\mathrm{CaO})$ is formed. ${ }^{31,32}$ The processing temperature should be below the decomposition temperature of calcite, which is about $720-900^{\circ} \mathrm{C} . .^{1,15}$ The band at $472 \mathrm{~cm}^{-1}$ belongs to hematite.

Figure 9 shows the bands of iron oxide around 672 $\mathrm{cm}^{-1}$ and $577 \mathrm{~cm}^{-1}$, which is typical of spined structures. Hematite is observed ${ }^{16}$ from the presence of peaks at 540 $\mathrm{cm}^{-1}$ and $470 \mathrm{~cm}^{-1}$. The presence of magnetite and hematite provides new information about the firing conditions. The firing conditions greatly influence the iron oxides; in fact, they differ in color according to the firing conditions. When oxygen is almost absent in the kiln under reducing conditions, reduced compounds, such as blackcolored pottery such as magnetite form. In contrast, un-

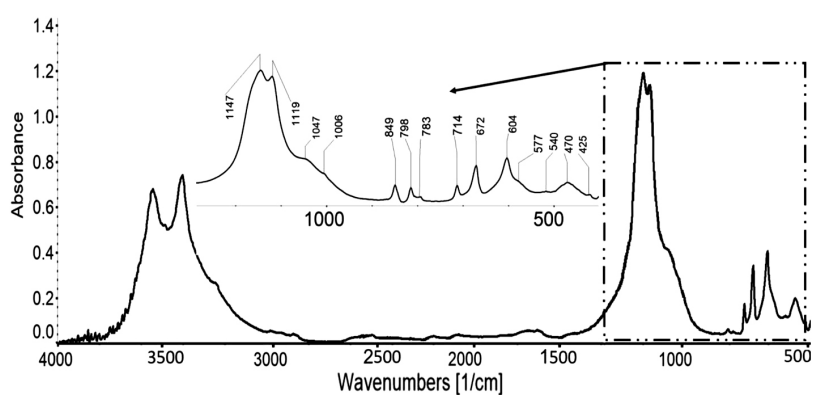

Figure 9: FTIR spectra of the sherd part after refiring by $1100{ }^{\circ} \mathrm{C}$ from $\left(1^{\text {st }}\right.$ century AD), sample 5 . The spectrum shows a disappearance of the main calcite band at $1442 \mathrm{~cm}^{-1}$ and the $875 \mathrm{~cm}^{-1}$ of the calcite $\left(\mathrm{CaCO}_{3}\right)$ bands at $1442 \mathrm{~cm}^{-1}$ and $875 \mathrm{~cm}^{-1}$ allows us to conclude the firing temperature. der oxidizing conditions, the oxidized form of pottery has a reddish color or hematite. The presence of hematite in some findings could give further information about the provenance of the clay used for the mixture. The essential minerals in refired pottery are iron oxides, quartz, and feldspars.

\section{CONCLUSIONS}

The use of FTIR spectroscopy in combination with SEM-EDX, and XRD for the investigation of ancient pottery artifacts provides an exceptional understanding of the technological basics applied to the production of the pottery objects, and it was found that they contain useful information on the analytical composition of the ancient Petra egg-shell pottery shards. Quartz, kaolinite, hematite, and calcite were found in all the samples. The calcite concentration was consistent in all pottery sherds, but the presence of calcite also showed that $\mathrm{CO}_{3}$ is primary and occurs as an impurity in the local clays when the sherds were refired the calcite band disappeared. The feldspar phases were obtained from the spectrum profiles of the FTIR spectra of refired pottery. The absence of a firing mineral in the pottery sherd is a reliable indicator of a low firing temperature. The black coloration was due to different concentrations of iron oxide, both magnetite and hematite. The comparison of the FTIR profiles spectra of the original and the corresponding refired at $1000{ }^{\circ} \mathrm{C}$ pottery fragments allows us to estimate the upper limit of the firing temperature between $800{ }^{\circ} \mathrm{C}$ and $900{ }^{\circ} \mathrm{C}$.

\section{Acknowledgments}

This study was supported by DFG; the authors would like to thank Prof. Jürgen Popp, the Scientific Director of the Institute of Photonic Technology, Jena, for FTIR and SEM-EDX examinations and Yarmouk University for the XRD measurements.

\section{REFERENCES}

${ }^{1}$ F. Villeneuve, Z. Al Muheissen, Nouvelles recherches à Khirbet edhDharih (Jordanie du sud, 1996-1999), Comptes rendus des séances de l'Académie des Inscriptions et Belles-Lettres, 144 (2000) 1525-1563

${ }^{2}$ F. Villeneuve, The Pottery from the Oil-Factory at Khirbet Edh-Dharih (2nd Century AD). A Contribution to the Study of the Material Culture of Nabataeans, Aram Periodical, 2 (1990) 367-384

${ }^{3}$ M. Tite, S. Herringer, A. Shortland, M. Matin, T. Pradell, S. Alcock, Production technology of Nabataean painted pottery compared with that of Roman terra sigillata, Journal of Archaeological Science: Reports, 21 (2018) 1073-1078, doi:10.1016/j.jasrep.2016.09.010

${ }^{4}$ H. D. Bienert, B. Müller-Neuhof, U. Wagner-Lux, G. P. I. o. A. i. Amman, I. Liedgens, At the Crossroads: Essays on the Archaeology, History and Current Affairs of the Middle East, German Protestant Institute of Archaeology in Amman, 2000

${ }^{5}$ W. D. Kingery, P. B. Vandiver, Ceramic Masterpieces: Art, Structure, and Technology, Free Press, 1986 
${ }^{6}$ C. Măruțoiu, I. Bratu, M. Țiplic, V. Măruțoiu, O. Nemeş, C. Neamțu, A. Hernanz, FTIR analysis and 3D restoration of ransylvanian popular pottery from the XVI-XVIII centuries, Journal of rchaeological Science: Reports, 19 (2018) 148-154,doi:10.1016/j.jasrep.2018. 02.044

${ }^{7}$ M. D. Carbó, F. B. Reig, J. G. Adelantado, V. P. Martinez, Fourier transform infrared spectroscopy and the analytical study of works of art for purposes of diagnosis and conservation, Analytica Chimica Acta, 330 (1996) 207-215, doi:10.1016/0003-2670(96)00177-8

${ }^{8}$ J. C. Shearer, D. C. Peters, G. Hoepfner, T. Newton, FTIR in the service of art conservation, Analytical Chemistry, 55 (1983) 874A-880A, doi:10.2307/1506280

${ }^{9}$ J. Mills, R. White, Organic chemistry of museum objects, Routledge, 2012

${ }^{10}$ T. J. Reedy, C. L. Reedy, Statistical analysis in art conservation research, Getty Publications, 1988

${ }^{11}$ M. Matteini, A. Moles, Scienza e restauro, Metodi di indagine, 1984

${ }^{12}$ R. Van Schoute, H. Verougstraete-Marcq, Scientific Examination of Easel Paintings: Art History and Laboratory: Published on the Occasion of the Xth Anniversary Meeting of the PACT Group at Louvain-la-Neuve, 1986, Conseil de l'Europe, 1986

${ }^{13}$ L. Masschelein-Kleiner, Scientific examination of easel paintings, Verougstraete-Marcq, Lovain-la-Neuve, (1986) 185-207

${ }^{14}$ D. Camuffa, A. Bernardi, Study of the microclimate of the Hall of the Giants in the Carrara Palace in Padua, Studies in conservation, 40 (1995) 237-249, doi:10.1179/sic.1995.40.4.237

${ }^{15}$ E. Dahlin, Preventive conservation strategies for organic objects in museums, historic buildings and archives, in: 5th EC Conference report "Cultural Heritage Research: a pan European Challenge, 2002

${ }^{16}$ G. S. Young, I. N. Wainwright, The control of algal biodeterioration of a marble petroglyph site, Studies in Conservation, 40 (1995) 82-92, doi:10.2307/1506507

${ }^{17}$ M. E. Laver, I. N. Wainwright, An investigation of the dissolution of a marble petroglyph site by acidic precipitation, Studies in conservation, 40 (1995) 265-273, doi:10.1179/sic.1995.40.4.265
${ }^{18}$ C. Degrigny, O. Morel, J. Morvan, J. Maire, S. Boucard, Nettoyage et stabilisation de surfaces métalliques peintes: application à la restauration d'une voiture autochenille, Studies in conservation, 40 (1995) 227-236, doi:10.1179/sic.1995.40.4.227

${ }^{19}$ E. Simpson, The Adventure of the Illustrious Scholar: Papers Presented to Oscar White Muscarella, Brill, 2018

${ }^{20}$ P. Alpass, The Religious Life of Nabataea, Brill, 2013

${ }^{21}$ J. Patrich, Was Dionysos, the wine god, venerated by the Nabataeans?, ARAM Periodical, 17 (2005) 95-113

${ }^{22}$ T. ERICKSON-GINI, Oboda and the Nabateans, STRATA: Bulletin of the Anglo-Israel Archaeological Society, 32 (2014)

${ }^{23}$ P. Lenoble, Z. al-Muheisen, F. Villeneuve, C. Augé, R. Boyer, A. Chambon, A. Desreumaux, F. Le Mort, D. al-Muheisen-Tarrier, L. Nehmé, Fouilles de Khirbet edh-Dharih (Jordanie), I: le cimetière au sud du Wadi Sharheh, Syria, (2001) 89-151

${ }^{24}$ C. Papachristodoulou, A. Oikonomou, K. Ioannides, K. Gravani, A study of ancient pottery by means of X-ray fluorescence spectroscopy, multivariate statistics and mineralogical analysis, Analytica Chimica Acta, 573 (2006) 347-353, doi:10.1016/j.aca.2006.02.012

${ }^{25}$ M. Sendova, V. Zhelyaskov, M. Scalera, M. Ramsey, Micro-Raman spectroscopic study of pottery fragments from the Lapatsa tomb, Cyprus, ca 2500 BC, Journal of Raman Spectroscopy: An International Journal for Original Work in all Aspects of Raman Spectroscopy, Including Higher Order Processes, and also Brillouin and Rayleigh Scattering, 36 (2005) 829-833, doi:10.1002/jrs.1371

${ }^{26}$ U.M.I.J.T.I. Service, Japanese Technical Abstracts, University Microfilms International, 1986

${ }^{27}$ P. Åström, Opuscula Atheniensia, Svenska institutet i Athen, 1988

${ }^{28}$ P. Colomban, Natural nanosized raw materials and Sol-Gel technology: the base of pottery since millenniums, in: Nanoscience and Cultural Heritage, Springer, 2016, 59-73, doi:10.????? 